J. Amer. Soc. Hort. Sci. 115(4):634-639. 1990.

\title{
Photosynthetic Evaluation of Sweetpotato Germplasm
}

\begin{abstract}
Ajmer S. Bhagsari
Agricultural Research Station, Fort Valley State College, Fort Valley, GA 31030

Additional index words. leaf area index, canopy photosynthesis, single leaf net photosynthesis, stomatal density, abaxial stomatal conductance, harvest index, phytomass

Abstract. Field experiments were conducted from 1980-1983 to evaluate sweetpotato [Ipomoea batatas (L.) Lam.] germplasm for photosynthetic efficiency, harvest index [HI; (storage root dry matter/total plant dry matter) $\times 100$ ], and yield. Most genotypes maintained leaf area index (LAI) above five until final harvest, 164 days after planting (DAP). The higher LAI (> 8) for PI 318859, PI 344134, and PI 308205 compared to the other genotypes was maintained at the expense of the storage root development. Single leaf net photosynthesis (Pn) of the genotypes ranged from 0.61 to $1.09 \mathrm{mg} \mathrm{CO} / \mathrm{m}^{2}$ per sec during 1980 . Canopy photosynthesis on a ground area (CPn-Ga) basis ranged from 0.95 to 1.56 and 1.04 to $1.30 \mathrm{mg} \mathrm{CO} / \mathrm{m}^{2}$ per sec during July and August 1983, respectively. Canopy photosynthesis expressed on leaf dry-weight (CPn-Dwt) basis was higher for PI 344122 than the other genotypes, except PI 344138, indicating its superior photosynthetic efficiency. Photosynthetic efficiency and stomatal conductance were not related to yield. Stomatal conductance and CPn-Ga were significantly correlated. Harvest index differed significantly at each sampling and ranged from $14.0 \%$ to $75.5 \%$ at final harvest. Fresh storage root yield for 1983 and 4-year mean yield ranged from 8.6 to 60.1 and 14.1 to 42.2 th ha ${ }^{-1}$ respectively. At final harvest, HI correlated significantly with fresh$(r=0.91)$ and dry-matter storage root yield $(r=0.95)$. Despite significant photosynthetic variations among the genotypes, sweetpotato yield was influenced more by HI and storage root sink strength than by photosynthetic efficiency.
\end{abstract}

Sweetpotato, an important vegetable crop in the southeastern United States, is mainly grown for human consumption. Previous research has focused on the development of' "table type"

Received for publication 18 July 1989. The cost of publishing this paper was defrayed in part by the payment of page charges. Under postal regulations, this paper therefore must be hereby marked advertisement solely to indicate this fact. (sweet type) sweetpotato cultivars with desirable horticultural traits and wide consumer acceptance (Harmon et al., 1970). The "industrial types" (nonsweet types) are generally grown in tropical and subtropical areas of the world for human consumption, animal feeding, and industrial uses (Sakamoto and Bouwkamp, 1985).

The energy crisis of the 1970s and subsequent escalating fuel costs stimulated the search for alternative renewable energy re- 
sources. Due to high starch production per unit of land area, root crops, including sweetpotato, hold potential in the production of ethanol for use as liquid fuel (Hammond, 1977).

Considerable interest has been shown in the United States for the use of sweetpotato as an alternative renewable energy resource to produce ethanol for fuel use (Hall and Smittle,. 1983; Hamilton et al., 1986; Jones et al., 1982; Wu and Bagby, 1987). In some other countries, nonsweet-type cultivars have been developed for industrial uses (Sakamoto and Bouwkamp, 1985).

Martin (1983) and Villareal et al. (1979) showed that plant introductions (PIs) generally yield more than the sweet types grown in the United States. A large collection of nonsweet-type PIs has been maintained by A. Jones at the U.S. Vegetable Laboratory, Charleston, S.C., as part of his sweetpotato germplasm resource. Limited information is available on the physiology and field evaluations of sweetpotato PIs. It may be possible to identify high-yielding PIs for potential use as industrial types in the United States.

The objective of this research was to evaluate sweetpotato germplasm, consisting mainly of PIs, for photosynthetic efficiency, harvest index, and yield.

\section{Materials and Methods}

Sweetpotato field experiments were conducted from 1980 through 1983 at the Agricultural Research Station, Fort Valley State College, Ga. During 1980, 40 genotypes, consisting of 24 PIs and 16 U.S. genotypes, were obtained from the U.S. Vegetable Laboratory in. Charleston. They were evaluated for single leaf net photosynthesis, stomatal density, and storage root yield. The sweetpotato slips for subsequent planting were obtained from storage roots saved from the previous crop. They were bedded in mid-March each year under clear plastic for 3 weeks and thereafter grew in the open until ready for transplanting. During 1981 and 1982, only 30 sweetpotato genotypes were field-tested because 10 genotypes did not form viable storage roots. Based on photosynthesis, percent storage root dry matter, and yield, only 15 genotypes were selected to determine canopy photosynthesis, stomatal conductance, and HI during 1983.

All studies were conducted using randomized complete-block designs with four replications. Slips were transplanted 2 June 1980, 27 and 29 May 1981, and 20 and 21 May 1982 in onerow plots $8.0 \mathrm{~m}$ long, $1.2 \mathrm{~m}$ apart, with $0.3 \mathrm{~m}$ between plants. During 1983, slips were transplanted on 20 May in three-row experimental plots $8.0 \times 3.6 \mathrm{~m}$ with $1.2 \mathrm{~m}$ between beds and $0.3 \mathrm{~m}$ between plants. Tests were conducted in a Norfolk sandy loam soil (fine-loamy, siliceous, thermic Typic Paleudult). Split fertilizer applications of one-half of $50 \mathrm{~N}-44 \mathrm{P}-123 \mathrm{~K}\left(\mathrm{~kg} \cdot \mathrm{ha}^{-1}\right)$ were made before ridging and before hilling, $\approx 40$ DAP. $N, N$ dimethyl $-\alpha$-phenylbenzeneacetamide (diphenamid) was applied

Table 1. Mean maximum (Max) and minimum (Min) temperatures $\left({ }^{\circ} \mathrm{C}\right)$ during sweetpotato growing season. ${ }^{2}$

\begin{tabular}{lcccccccc}
\hline & \multicolumn{2}{c}{1980} & \multicolumn{2}{c}{1981} & \multicolumn{2}{c}{1982} & \multicolumn{2}{c}{1983} \\
\cline { 2 - 8 } Month & Max & Min & Max & Min & Max & Min & Max & Min \\
\hline May & 27.9 & 15.5 & 27.0 & 12.8 & 29.2 & 15.2 & 28.7 & 13.9 \\
June & 31.3 & 19.2 & 33.9 & 21.1 & 31.6 & 19.1 & 30.0 & 17.8 \\
July & 35.5 & 22.0 & 34.8 & 21.9 & 31.4 & 21.0 & 33.9 & 21.1 \\
August & 35.5 & 21.4 & 29.7 & 20.0 & 31.4 & 20.2 & 34.5 & 21.1 \\
September & 32.5 & 19.6 & 29.9 & 15.9 & 29.3 & 16.4 & 28.9 & 16.7 \\
October & 23.1 & 10.1 & 23.2 & 9.9 & 25.5 & 10.8 & 25.0 & 11.7 \\
\hline
\end{tabular}

${ }^{7}$ Temperature data were obtained from Southeastern Fruit and Tree Nut Lab., USDA, Byron, Ga. at $2.0 \mathrm{~kg} \cdot \mathrm{ha}^{-1}$ after transplanting. Sprinkler irrigation was used for watering the plants. During 1980, eight irrigations, $50 \mathrm{~mm}$ each, were applied. During the subsequent years, the number of irrigations varied from three to five.

Plant samples. Plant samples were taken, two plants per plot, 21-29 July and 9-11 Sept. only during 1983. For September plant sampling, a wooden frame $(0.6 \times 1.2 \mathrm{~m})$ with a sharp blade fitted on all lower sides, was placed at random in the middle row of each plot. All the phytomass inside the wooden frame was collected, including dry leaves and petioles, At final harvest, plants grown within the concrete bases (see canopy photosynthesis, below) were harvested separately. They were separated into leaves, branches and petioles, and storage roots. Only roots $>2.5 \mathrm{~cm}$ in diameter were included in storage root yield, but all the roots were included in phytomass. Leaf area was determined with a leaf area meter (Model LI-3100, LI$\mathrm{COR}$, Lincoln, Neb.). Plant material was dried at $60 \mathrm{C}$ to a constant weight before recording dry weights. Harvest index was calculated by dividing the storage root dry matter by the total plant dry matter, excluding fallen leaves and petioles and multiplying by 100 .

Stomatal density and stomatal conductance. Stomatal density was determined from leaf impressions made with Rhoplex, Grade AC-33 (Rohm and Hass, Charlotte, N.C.), only during midSeptember 1980 as described by Bhagsari (1981). The abaxial stomatal conductance was determined with a steady-state porometer (Model LI-1600, LI-COR) on the second or third fully mature and expanded leaves from the vine tip on 28 Aug., 2 Oct., and 27-29 Oct. 1983, between 1100 and 1500 HR in full sunlight.

Single leaf net photosynthesis. The Pn was determined 29 Aug. to 4 Sept. and 16-21 Sept, 1980 in an open system with an infrared $\mathrm{CO}_{2}$ analyzer (Beckman, Model $215 \mathrm{~B}$ ) between 1100 and 1500 HR on sunny days (light intensity >1500 $\mu \mathrm{mol} \cdot \mathrm{s}^{-1} \cdot \mathrm{m}^{-2}$ ). The Pn was measured on fully expanded and mature attached leaves by enclosing them in a plexiglass photosynthesis chamber at $30 \pm 2 \mathrm{C}$. Humidified compressed air, breathing quality, containing $330 \mu \mathrm{l} \mathrm{CO}_{2} /$ liter was passed through tygon tubing and over the leaf at 6.0 liter $\cdot \mathrm{min}^{-1}$. Other Pn measurement information has previously been reported (Bhagsari, 1981; Bhagsari and Harmon, 1982).

Canopy photosynthesis. During 1983, 15 genotypes were selected and planted in three-row plots as described above. After hilling the plants 40 DAP, four plants from the middle row of each experimental plot were enclosed with a 10.0-cm-wide rectangular concrete base $(1.37 \times 1.22 \mathrm{~m})$ with a 3.5 -cm-wide groove on top to hold water for making the system airtight during CPn measurement. The inner wall of the concrete base used four steel rods, $0.60 \mathrm{~m}$ high and enclosing $\approx 1.0 \mathrm{~m}^{2}$, to support poultry mesh wire for containment of sweetpotato vines. The vines protruding from the poultry mesh wire were regularly returned to the enclosed area.

A plexiglass photosynthetic chamber $1.26 \times 1.12 \times 0.68$ $\mathrm{m}$ high, fitting the groove in the concrete base, was constructed for CPn measurement as described by Bhagsari (1988). The photosynthetic chamber was provided with two squirrel-cage fans for air turbulence and a thermocouple to monitor temperature during $\mathrm{CPn}$ measurement.

An infrared analyzer, housed in a trailer at the experimental site, was used to measure CPn on sunny days (>1500 $\mu \mathrm{mol} \cdot \mathrm{s}^{-1} \cdot \mathrm{m}^{-2}$ ) between 1100 and $1500 \mathrm{HR}$ on 18-20 July, 1015 Aug., 3-8 Oct., and 26-28 Oct. 1983. The infrared analyzer was calibrated in a differential mode with breathing air having 
Table 2. Single leaf net photosynthesis (Pn), stomatal density, yield, and percent dry matter of sweetpotato genotypes, $1980-82$.

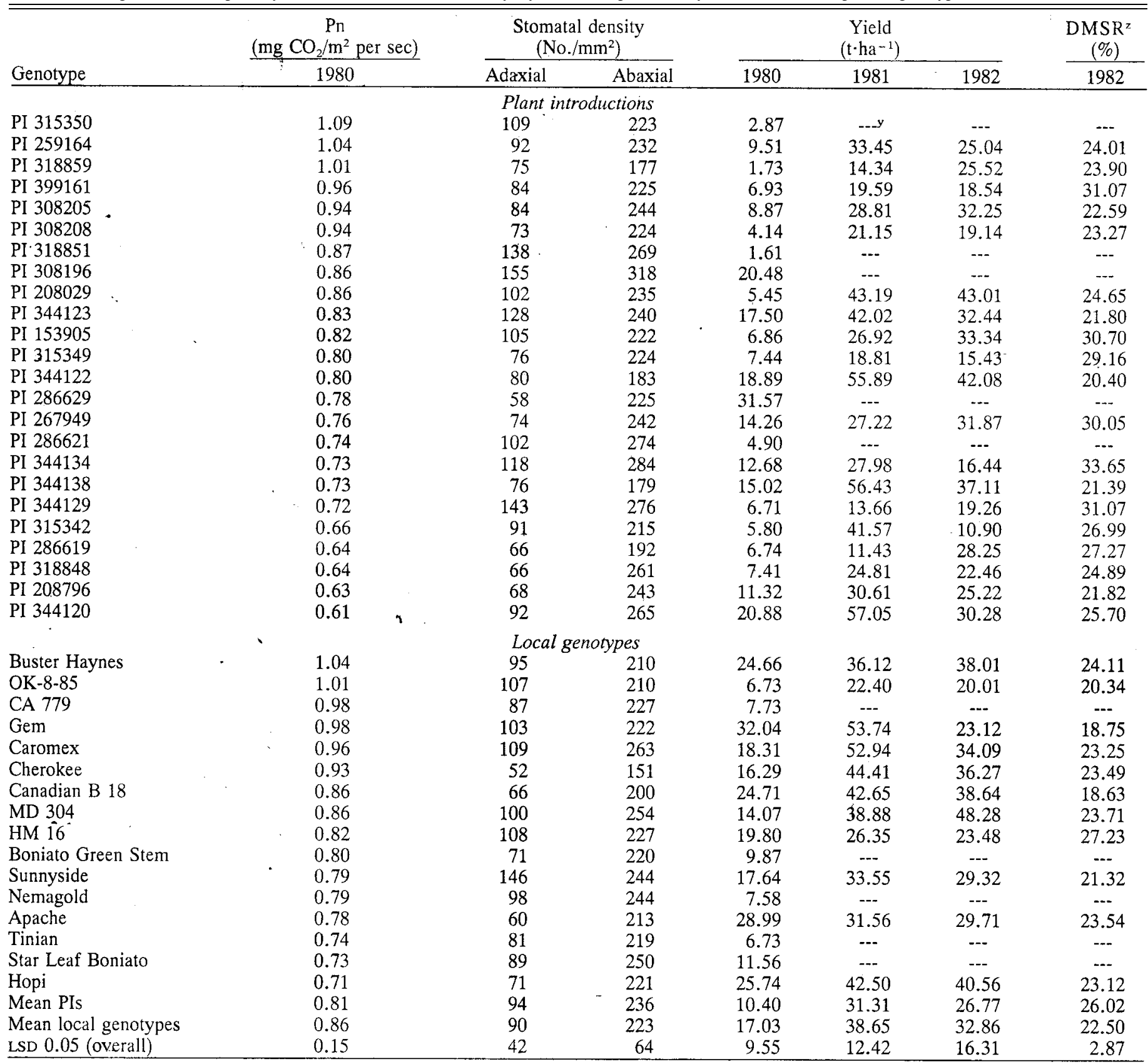

${ }^{2}$ Percent dry matter storage roots.

${ }^{y}$ Dashes indicate that no data are available.

260 and $360 \mu \mathrm{CO}_{2} /$ liter. For 26-28 Oct. 1983, canopy photosynthesis was also expressed on leaf-area (CPn-La) and leafdry-weight (CPn-Dwt) bases. Other relevant details for CPn measurement have been reported earlier (Bhagsari, 1988).

Temperature data. The mean monthly minimum and maximum temperatures from May to October during the sweetpotato growing period ranged from 9.9 to $22.0 \mathrm{C}$ and 23.1 to $35.5 \mathrm{C}$, respectively (Table 1). During 1980, mean maximum monthly temperature for July, August, and September was higher than for the corresponding periods from 1981 to 1983.

Data analysis. Analysis of variance procedures were used to analyze the data. The correlation coefficients were calculated on treatment means.

\section{Results and Discussion}

Single leaf net photosynthesis. The Pn differed significantly among sweetpotato genotypes and ranged from 0.61 to $1.09 \mathrm{mg}$ $\mathrm{CO}_{2} / \mathrm{m} 2$ per sec (Table 2). The mean Pn rates for the 16 local genotypes and 24 PIs were 0.86 and $0.81 \mathrm{mg} \mathrm{CO} / \mathrm{m}^{2}$ per sec, respectively. The range in Pn among these genotypes was similar to those in previous reports (Bhagsari, 1981; Bhagsari and Harmon, 1982).

Stomatal density. Both adaxial and abaxial stomatal densities differed significantly, ranging from 52 to $155 \mathrm{~mm}^{-2}$ and 151 to $318 \mathrm{~mm}^{-2}$, respectively (Table 2). Stomatal densities for both surfaces were the lowest for 'Cherokee' and the highest for PI 308196. The mean stomatal densities for the local cultivars and 
Table 3. Leaf area index (LAI), canopy photosynthesis, and stomatal conductance of selected sweetpotato genotypes on given days after planting, 1983.

\begin{tabular}{|c|c|c|c|c|c|c|c|c|c|c|c|}
\hline \multirow[b]{5}{*}{ Genotype } & & & \multicolumn{6}{|c|}{ Canopy photosynthesis } & \multirow{2}{*}{\multicolumn{3}{|c|}{$\begin{array}{c}\text { Stomatal conductance } \\
\text { Abaxial }\end{array}$}} \\
\hline & \multicolumn{2}{|c|}{ LAI } & \multicolumn{4}{|c|}{$\mathrm{CPn}-\mathrm{Ga}^{2}$} & \multirow{2}{*}{$\frac{\mathrm{Cpn}-\mathrm{La}^{\mathrm{y}}}{26 \text { Oct. }}$} & \multirow{2}{*}{$\frac{\mathrm{CPn}^{-\mathrm{Dw}} \mathrm{t}^{\mathrm{x}}}{26 \text { Oct. }}$} & & & \\
\hline & 21 July & 31 Oct. & 18 July & 10 Aug. & 3 Oct. & 26 Oct. & & & 28 Aug. & 2 Oct. & 28 Oct. \\
\hline & \multicolumn{11}{|c|}{ Days after planting } \\
\hline & 62 & 164 & 59 & 82 & 136 & 159 & 159 & 159 & 89 & 135 & 161 \\
\hline & \multicolumn{2}{|c|}{ Ratio w $^{\text {w }}$} & \multicolumn{5}{|c|}{$m g \mathrm{CO}_{2} / \mathrm{m}^{2}$ per sec } & $m g \mathrm{CO}_{2} / \mathrm{kg} \mathrm{per} \mathrm{sec}$ & & $\mathrm{cm} \cdot \mathrm{s}^{-1}$ & \\
\hline PI $31534^{\circ}$ & 5.94 & 5.32 & 1.42 & 1.04 & 0.87 & 0.30 & 0.06 & 2.05 & 1.09 & 0.86 & 0.19 \\
\hline PI 344134 & 5.85 & 13.92 & 1.56 & 1.06 & 1.12 & 0.86 & 0.07 & 2.59 & 1.21 & 0.89 & 0.41 \\
\hline PI 344122 & 5.68 & 7.47 & 1.43 & 1.19 & 1.08 & 0.86 & 0.12 & 6.09 & 0.88 & 1.28 & 0.59 \\
\hline PI 153905 & 5.52 & 6.00 & 1.30 & 1.25 & 1.16 & 0.65 & 0.10 & 3.58 & 1.03 & 1.37 & 0.53 \\
\hline PI 318859 & 5.13 & 14.18 & 1.20 & 1.30 & 1.02 & 0.78 & 0.07 & 3.15 & 1.12 & 1.47 & 0.70 \\
\hline Apache & 4.93 & 5.95 & 1.18 & 1.08 & 0.94 & 0.27 & 0.05 & 2.23 & 1.16 & 1.18 & 0.32 \\
\hline PI 308205 & 4.91 & 8.88 & 1.47 & 1.24 & 0.85 & 0.63 & 0.08 & 4.31 & 1.01 & 1.31 & 0.60 \\
\hline PI 344138 & 4.86 & 7.08 & 1.19 & 1.25 & 0.96 & 0.82 & 0.11 & 4.86 & 0.68 & 1.12 & 0.68 \\
\hline Sunnyside & 4.64 & 5.21 & 1.32 & 1.24 & 1.02 & 0.22 & 0.05 & 2.14 & 1.02 & 1.16 & 0.26 \\
\hline Hopi & 4.61 & 4.69 & 1.19 & 1.20 & 0.72 & 0.28 & 0.06 & 2.16 & 1.02 & 0.99 & 0.29 \\
\hline PI 344120 & 4.46 & 7.11 & 1.29 & 1.20 & 0.89 & 0.48 & 0.06 & 3.31 & 0.94 & 1.18 & 0.48 \\
\hline PI 286619 & 4.44 & 7.69 & 0.95 & 1.12 & 1.07 & 0.42 & 0.06 & 2.67 & 0.99 & 1.24 & 0.37 \\
\hline PI 267949 & 4.39 & 6.14 & 1.26 & 1.16 & 0.98 & 0.43 & 0.07 & 3.01 & 1.34 & 1.31 & 0.42 \\
\hline PI 208796 & 4.04 & 6.36 & 1.04 & 1.21 & 1.11 & 0.29 & 0.04 & 1.49 & 0.96 & 1.12 & 0.49 \\
\hline PI 208029 & 3.54 & 5.23 & 1.18 & 1.11 & 1.03 & 0.55 & 0.10 & 4.01 & 0.98 & 1.34 & 0.40 \\
\hline Mean & 4.86 & 7.42 & 1.27 & 1.18 & 0.99 & 0.52 & 0.07 & 3.18 & 1.03 & 1.19 & 0.45 \\
\hline LSD 0.05 & 1.13 & 4.27 & 0.24 & 0.19 & 0.31 & 0.19 & 0.03 & 1.42 & 0.38 & 0.24 & 0.17 \\
\hline
\end{tabular}

${ }^{2} \mathrm{CPn}-\mathrm{Ga}=$ Canopy photosynthesis expressed on ground-area basis.

${ }^{\mathrm{y}} \mathrm{CPn}-\mathrm{La}=$ Canopy photosynthesis expressed on leaf-area basis.

${ }^{x} \mathrm{CPn}-\mathrm{Dwt}=$ Canopy photosynthesis expressed on leaf-dry-weight basis.

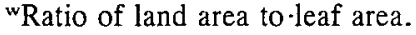

Table 4. Harvest index, phytomass, yield, and number of storage roots per plant for sweetpotatoes on given days after planting, 1983.

\begin{tabular}{|c|c|c|c|c|c|c|c|c|c|}
\hline \multirow[b]{4}{*}{ Genotype } & \multicolumn{3}{|c|}{ Harvest index } & \multicolumn{2}{|c|}{ Phytomass $^{z}$} & \multirow{2}{*}{$\frac{\text { FSRYY }^{y}}{31 \text { Oct. }}$} & \multirow{2}{*}{$\begin{array}{c}\text { DMSRY }^{\mathrm{x}} \\
31 \text { Oct. }\end{array}$} & \multirow[b]{2}{*}{ Roots/plant } & \multirow{4}{*}{$\begin{array}{c}\text { 4-year } \\
\text { mean yield }\end{array}$} \\
\hline & 21 July & 9 Sept. & 31 Oct. & 21 July & 31 Oct. & & & & \\
\hline & \multicolumn{8}{|c|}{ Days after planting } & \\
\hline & 62 & 112 & 164 & 62 & 164 & 164 & 164 & 164 & \\
\hline & & $\%$ & & \multicolumn{4}{|c|}{$t \cdot h a^{-1}$} & No. & $t \cdot h a^{-1}$ \\
\hline PI 315349 & 15.7 & 25.3 & 66.5 & 5.6 & 17.0 & 37.3 & 11.2 & 7.3 & 19.6 \\
\hline PI 344134 & 5.8 & 12.4 & 14.0 & 6.3 & 17.5 & 8.6 & 2.4 & 2.7 & 16.4 \\
\hline PI 344122 & 26.1 & 33.9 & 60.0 & 6.2 & 18.0 & 48.2 & 10.6 & 3.1 & 41.3 \\
\hline PI 153905 & 23.6 & 30.4 & 61.3 & 7.0 & 21.1 & 42.7 & 12.9 & 4.3 & 27.5 \\
\hline PI 318859 & 5.2 & 16.7 & 20.9 & 5.6 & 16.2 & 14.7 & 3.5 & 1.6 & 14.1 \\
\hline Apache & 43.3 & 64.0 & 75.5 & 5.7 & -17.6 & 57.1 & 13.3 & 8.7 & 36.8 \\
\hline PI 308205 & 17.5 & 23.7 & 23.9 & 5.9 & 12.8 & 14.1 & 2.9 & 3.5 & 21.0 \\
\hline PI 344138 & 16.2 & 33.1 & 49.3 & 4.8 & 16.4 & 49.3 & 8.1 & 3.1 & 39.5 \\
\hline Sunnyside & 33.9 & 44.9 & 63.2 & 5.7 & 15.4 & 54.6 & 9.9 & 6.5 & 33.8 \\
\hline Hopi & 38.3 & 48.0 & 74.3 & 5.7 & 18.5 & 60.1 & 13.7 & 4.8 & 42.2 \\
\hline PI 344120 & 21.8 & 38.4 & 62.3 & 6.0 & 21.4 & 56.0 & 13.0 & 3.5 & 41.1 \\
\hline PI 286619 & 28.1 & 38.0 & 49.4 & 4.6 & 12.5 & 27.9 & 6.2 & 3.6 & 18.6 \\
\hline PI 267949 & 36.9 & 46.1 & 71.1 & 5.7 & 16.0 & 46.3 & 11.4 & 6.4 & 29.9 \\
\hline PI 208796 & 23.0 & 35.8 & 59.6 & 4.4 & 16.7 & 51.1 & 10.0 & 6.0 & 29.6 \\
\hline PI 208029 & 35.5 & 37.3 & 62.7 & 5.7 & 18.8 & 57.2 & 11.7 & 9.4 & 37.2 \\
\hline Mean & 24.7 & 35.2 & 54.3 & 5.7 & 17.1 & 41.7 & 9.4 & 5.0 & 29.9 \\
\hline LSD 0.05 & 14.5 & 14.3 & 11.2 & 1.1 & 3.3 & 7.8 & 3.1 & 1.8 & -- \\
\hline
\end{tabular}

${ }^{2}$ Phytomass $=$ phytomass taken 21 July from field samples and 31 Oct. from enclosed area for photosynthesis measurement.

${ }^{\mathrm{y}} \mathrm{FSRY}=$ fresh storage root yield from enclosed area for photosynthesis measurement.

${ }^{\mathrm{D}} \mathrm{DMSRY}=\mathrm{dry}$-matter storage root yield from enclosed area for photosynthesis measurement.

PIs were similar to those reported previously (Bhagsari, 1981; Bhagsari and Harmon, 1982).

Yield. For 1981 and 1982, the mean storage root yield was more than twice as large as for 1980 (Table 2). From 1980 to 1982 , the mean storage root yield of PIs was lower than the local genotypes. The percent dry matter in storage roots ranged from 18.6 to 33.6 .

Leaf area index. The LAI differed significantly among the 15 selected sweetpotato genotypes (Table 3 ). LAI ranged from 3.54 to 5.94 and 4.69 to 14.18 for 21 July and 31 Oct. 1983, 
Table 5. Correlation coefficients $(r)$ among photosynthesis and other traits of sweetpotato during 1983.

\begin{tabular}{ll}
\hline Traits & \multicolumn{1}{c}{$r$} \\
\hline CPn-Ga 18 July vs. leaf area index 21 July. & $0.67^{* *}$ \\
CPn-Ga 26 Oct. vs. leaf area index 28 Oct. & $0.67^{* *}$ \\
CPn-Ga 18 July vs. phytomass 21 July & $0.71^{* *}$ \\
CPn-Ga 10 Aug. vs. SCy 2 Oct. & $0.57^{*}$ \\
CPn-Ga 10 Aug. vs. SC 28 Oct. & $0.68^{* *}$ \\
CPn-Ga 26 Oct. vs. SC 28 Oct. & $0.76^{* *}$ \\
CPn-Lax 26 Oct. vs. SC 28 Oct. & $0.75^{* *}$ \\
CPn-Ga 26 Oct. vs. HI 21 July & $-0.55^{*}$ \\
CPn-Ga 26 Oct. vs. HI 9 Sept. & $-0.70^{* *}$ \\
CPn-Ga 26 Oct. vs. HI 31 Oct. & $-0.67^{* *}$ \\
CPn-Ga 26 Oct. vs. roots/plant & $-0.67^{* *}$ \\
\hline
\end{tabular}

${ }^{z} \mathrm{CPn}-\mathrm{Ga}=$ canopy photosynthesis on ground-area basis.

${ }^{\mathrm{y}} \mathrm{SC}=$ stomatal conductance.

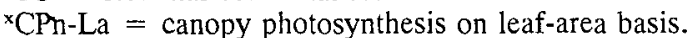

${ }^{\text {w } H I}=$ Harvest index.

*,**Significant at $P=0.05$ or 0.01 , respectively.

respectively. The mean LAI increased $52.7 \%$ from July to final harvest. While the percent increase in LAI was $<21 \%$ for the three local cultivars, the percent increase in LAI among the PIs, except PI 315349 , ranged from $\approx 9 \%$ to $176 \%$. With LAIs of Irish potato (Solanum tuberosum L.) in the range of 2.2 to 4.4 , $\approx 95 \%$ of photosynthetically active radiation was intercepted (Khurana and McLaren, 1982). Sweetpotatoes maintained LAI to intercept a major portion of sunlight until final harvest. The vines for PI 344134 and PI 318859 climbed over the poultry wire mesh during the later stages of growth, which may explain their very high LAIs.

Canopy photosynthesis. Significant variations existed in sweetpotato CPn during the 1983 growing season. The $\mathrm{CPn}-\mathrm{Ga}$ (canopy photosynthesis/unit ground area) ranged from 0.95 to 1.56 and 1.04 to $1.30 \mathrm{mg} \mathrm{CO}_{2} / \mathrm{m}^{2}$ per sec during July and August, respectively (Table 3). On 26 Oct. (159 DAP), the CPn-Ga ranged from 0.22 to $0.86 \mathrm{mg} \mathrm{CO}_{2} / \mathrm{m}^{2}$ per sec. The CPn-Ga was lower for the three local cultivars than for the PIs. This may be attributed in part to the earlier maturity of the local cultivars.

The CPn-La ranged from 0.04 to $0.12 \mathrm{mg} \mathrm{CO}_{2} / \mathrm{m}^{2}$ per sec. Except for PI 344138, the CPn-Dwt basis was also significantly higher for PI 344122 than for all other genotypes. These observations indicated the superior photosynthetic efficiency of PI 344122.

There was a significant $\mathrm{CPn}-\mathrm{Ga}$ measurement date $\times$ genotype interaction, indicating that ranking for photosynthetic rates differed among the genotypes at each measurement. The interaction may be attributed to variations in LAI development and differences in storage root development and storage root sink strength among the sweetpotato genotypes.

Stomatal conductance. The stomatal conductance ranged from 0.68 to 1.34 and 0.86 to $1.47 \mathrm{~cm} \cdot \mathrm{s}^{-1}$ for $28 \mathrm{Aug}$. and 2 Oct. 1983 , respectively (Table 3 ). The genotypic mean stomatal conductances of fully mature upper canopy leaves were similar on 28 Aug. and 2 Oct. 1983. The reduction in stomatal conductance from 2 Oct. to 28 Oct. was probably caused by low night temperature (Table 1) and plant age.

Harvest index and yield. The HI differed significantly for each sampling (Table 4). On 21 July (62 DAP), the HI ranged from $5.2 \%$ to $43.3 \%$. On 9 Sept., the HI for 'Apache' was significantly higher than that of the other genotypes. At final harvest, 31 Oct., the HI ranged from $14.0 \%$ to $75.5 \%$. The lower HI for many PIs may be due to the longer time required to enlarge storage roots.

Significant variations were found in phytomass and total freshand dry-matter storage root yields among the sweetpotato genotypes (Table 4). The phytomass yield ranged from 4.4 to 7.0 $\mathrm{t} \cdot \mathrm{ha}^{-1} 62$ DAP. At final harvest (164 DAP), phytomass yield for PI 344120 was higher than for the other genotypes, except PI 153905, PI 208029, and 'Hopi'. Fresh- and dry-matter storage root yields ranged from 8.7 to $60.1 \mathrm{t} \cdot \mathrm{ha}^{-1}$ and 2.4 to 13.7 $\mathrm{t} \cdot \mathrm{ha}^{-1}$, respectively.

At final harvest, storage roots per plant showed significant variations ranging from 1.6 to 9.4 (Table 4). Four-year mean fresh storage root yield for selected genotypes ranged from 14.1 to $42.2 \mathrm{t} \cdot \mathrm{ha}^{-1}$.

Correlation coefficients among selected traits. The CPn-Ga for July and 26 Oct. were significantly correlated with LAI (Table 5). The CPn-Ga for August was significantly correlated with stomatal conductance for 2 and 28 Oct. Also, during late October, both CPn-Ga and CPn-La were significantly correlated with stomatal conductance.

The CPn-Ga on 26 Oct. was negatively correlated with roots per plant and HI (Table 5). This result is attributed to the higher LAI of most of the PIs, resulting in higher CPn-Ga at the end of October. However, the HI of many PIs was low because of their late initiation of storage root sink development, despite the high CPn-Ga due to their greater LAIs, which explains the negative correlations between $\mathrm{HI}$ and $\mathrm{CPn}-\mathrm{Ga}$.

The HIs for each sampling date were significantly related to each other, indicating that dry-matter partitioning patterns remained similar during growth for most genotypes (Table 6). Fresh- and dry-matter storage root yields were significantly cor-

Table 6. Correlation coefficients $(r)$ among selected traits of sweetpotato for 1983.

\begin{tabular}{|c|c|c|c|c|c|c|c|c|}
\hline \multirow[b]{2}{*}{ Item } & \multicolumn{3}{|c|}{ Harvest index } & \multicolumn{2}{|c|}{ Phytomass } & \multirow{2}{*}{$\frac{\text { FSRY }^{2}}{31 \text { Oct. }}$} & \multirow{2}{*}{$\frac{\text { DMSRY }^{y}}{31 \text { Oct. }}$} & \multirow{2}{*}{$\frac{\text { Roots/plant }}{31 \text { Oct. }}$} \\
\hline & 21 July & 9 Sept. & 31 Oct. & 21 July & 31 Oct. & & & \\
\hline HIx 21 July & $-\cdots$ & $0.83^{* *}$ & $0.81 * *$ & NS & NS & $0.81^{* *}$ & $0.79 * *$ & $0.53^{*}$ \\
\hline HI 9 Sept. & & -- & $0.75^{* *}$ & NS & NS & $0.75^{* *}$ & $0.67^{* *}$ & $0.55^{*}$ \\
\hline HI 31 Oct. & & & & --- & $0.54 *$ & $0.91 * *$ & $0.95^{* *}$ & $0.67^{* *}$ \\
\hline Phytomass 21 July & & & & & --- & NS & NS & NS \\
\hline Phytomass 31 Oct. & & & & & & NS & $0.63^{* *}$ & NS \\
\hline FSRY & & & & & & & $0.91^{* *}$ & $0.58^{*}$ \\
\hline DMSRY & & & & & & & & $0.60^{*}$ \\
\hline
\end{tabular}

${ }^{2}$ FSRY $=$ Fresh storage root yield.

${ }^{y}$ DMSRY = Dry matter storage root yield.

${ }^{\mathrm{x}} \mathrm{HI}=$ Harvest Index.

${ }_{\text {NS },{ }^{, * * *}}$ Nonsignificant or significant at $P=0.05$ or 0.01 , respectively. 
related with HI. Roots per plant were also significantly correlated with fresh- and dry-matter storage root yields and HI, reflecting the influence of root sink on both fresh- and drymatter storage root yield.

Single leaf net photosynthesis showed no correlation with yield. As reported in studies on genotypic Pn evaluations (Bhagsari and Brown, 1986), differences in leaf sizes used for Pn measurement may confound the Pn rates. This, in turn, may affect the relationship between yield and Pn (Bhagsari and Brown, 1986). The leaf size ranged from 41.5 to $179 \mathrm{~cm}^{2}$ and it was negatively related to $\mathrm{Pn}(r=-0.31, \mathrm{P}=0.05)$. Further, PI 344120 , one of the three highest-yielding genotypes, had the lowest Pn during 1980. Thus, Pn evaluation using entire leaves is not a good tool to predict the yield potential of sweetpotato genotypes having different leaf sizes.

Maximum recorded $\mathrm{CPn}-\mathrm{Ga}$ rates occurred $\approx 60 \mathrm{DAP}$ with a mean LAI of $\approx 5.0$. The CPn-Ga declined at subsequent measurements, even with similar or increasing LAI values. The decrease in canopy photosynthetic rate was probably caused by increased proportion of aging leaves in the canopy.

Although stomatal conductance differed significantly among the genotypes during the early growth phase, it was not related to photosynthesis at that time or to the ultimate yield. By the end of October, stomatal conductance was inversely related to HI ( $r=-0.53, \mathrm{P}=0.05)$ but showed a significant positive correlation with LAI and CPn-Ga. These correlations are due to some PIs with late maturity maintaining physiologically active foliage and higher LAIs at the expense of HI and storage root yield.

The direction and magnitude of photosynthate translocation apparently varied among the sweetpotato genotypes. Some PIs, especially PI 344134 and PI 318859, continued partitioning significant amounts of photosynthate to leaves and branches at the expense of storage roots, as indicated by their higher LAIs and low yields. The number of storage roots was similar for PI 344134, PI 344120, and PI 344122. Yet, the mean yield for PI 344134 was less than one-half of the other two genotypes, which probably had higher storage root sink strengths. During 1981, one storage root for PI 344120 weighed $\approx 12.7 \mathrm{~kg}$. During 1983, PI 308205, PI 344134, and PI 318859 maintained high photosynthetic rates, similar to that of many other genotypes, but produced lower storage root yield than any of the other genotypes, except for PI 286619. Thus, low root yields cannot be explained by low photosynthetic rates.

Both storage root fresh- and dry-matter yields were strongly influenced by HI, as indicated by the positive correlations between HI and yield. The HIs for the three samplings were correlated. This is an indication that the percentage of photosynthate partitioned to storage roots remained consistent across growth stages. During 1983, PI 344134, PI 348859, and the three local cultivars accumulated similar phytomass at 164 DAP, but the storage root yields for the three local cultivars were three to four times higher than for the two PIs. Therefore, variations in the HIs accounted for the yield differences among these genotypes.

Research conducted with U.S. cultivars indicated that yield may be limited by the phytosynthate supply (Bouwkamp and Hassam, 1988). However, data from the present studies indicated that yield for most PIs was limited by the lack of storage root sinks and the translocation of photosynthate to storage roots, as also observed in other reports for U.S. cultivars (Austin and Lang, 1973) and PIs (Lowe and Wilson, 1974).

This research demonstrated that significant genetic variation exists among the PIs in canopy photosynthesis, HI, and storage root yield. Photosynthesis (Harrison et al., 1981) and HI (Kawano et al., 1978) are heritable traits and both traits influence yield. Thus, identification and use of genotypes having high photosynthetic rates and $\mathrm{HI}$ in a polycross nursery may lead to sweetpotato yield improvement.

\section{Literature Cited}

Austin, M.E. and L.H. Lang. 1973. Patterns of dry matter distribution during development of sweet potato. J. Hort. Sci. 48:11-17.

Bhagsari, A.S. 1981. Relation of photosynthetic rates to yield in sweet potato genotypes. HortScience 16:779-780.

Bhagsari, A.S. 1988. Photosynthesis and stomatal conductance of selected root crops as related to leaf age. Crop-Sci. 28:902-906.

Bhagsari, A.S. and R.H. Brown. 1986. Leaf photosynthesis and its correlation with leaf area. Crop Sci. 26: 127-132.

Bhagsari, A.S. and S.A. Harmon. 1982. Photosynthesis and photosynthate partitioning in sweet potato genotypes. J. Amer. Soc. Hort. Sci. 107:506-510.

Bouwkamp, J.C. and M.N.M. Hassam. 1988. Source-sink relationship in sweet potato. J. Amer. Soc. Hort. Sci. 113:627-629.

Hall, M.R. and D.A. Smittle. 1983. Industrial type sweet potatoes: A renewable energy source for Georgia. Ga. Agr. Expt. Sta. Res. Rpt. 429.

Hamilton, M.G., A. Jones, P.D. Dukes, and J.M. Schalk. 1986. Selection criteria for breeding sweet potatoes for industrial uses. HortScience 21:1426-1428.

Hammond, A.L. 1977. Alcohol: A Brazilian answer to the energy crisis. Science 195:564-566.

Harmon, S.A., H.L. Hammet, T. Hernandez, and D.T. Pope. 1970. Progress in the breeding and development of new varieties. Thirty years of cooperative sweet potato research 1939-1969. Southern Coop. Ser. Bul. no. 159:8-17.

Harrison, S.A., H.R. Boerma, and D.A. Ashley. 1981. Heritability of canopy-apparent photosynthesis and its relationship to seed yield in soybeans. Crop Sci. 21:222-226.

Jones, A., M.G. Hamilton, and P.D. Dukes. 1982. Sweet potato cultivars for ethanol production, p. 195-198. In: J.A. Haynie, (ed.). Proc. Third Annu. Solar and Biomass Energy Wkshp. USDA, Tifton, Ga.

Kawano, K., A. Amaya, P. Daza, and M. Rios. 1978. Factors affecting efficiency of hybridization and selection in cassava. Crop Sci. 18:373-376

Khurana, S.C. and J.S. McLaren. 1982. The influence of leaf area, light interception and season on potato growth and yield. Potato Res. 25:329-342.

Lowe, S.B. and L.A. Wilson. 1974. Comparative analysis of tuber development in six sweet potato [Ipomoea batatas (L.) Lam.] cultivars: 1. Tuber initiation, tuber growth and partition of assimilate. Ann. Bot. 38:307-317.

Martin, F.W. 1983. Variation of sweet potatoes with respect to the effects of waterlogging. Trop. Agr. 60:117-121.

Sakamoto, S. and J.C. Bouwkamp. 1985. Industrial products from sweet potatoes, p. 219-233. In: J.C. Bouwkamp (ed.). Sweet potato products: A natural resource for the tropics. CRC Press, Boca Raton, Fla.

Villareal, R.L., S.C.S. Tsou, S.K. Lin, and S.C. Chiu. 1979. Use of sweet potato (Ipomoea batatas) leaf tips as vegetables. H. Evaluation of yield and nutritive quality. Expt. Agr. 15:117-122.

Wu, Y.V. and Bagby, M.O. 1987. Recovery of protein rich by-products from sweet potato stillage following alcohol distillation. J. Agr. Food Chem. 35:321-325. 